\title{
Factors associated with urinary tract infection in a Nursing Home
}

\author{
Fatores associados à infecção de trato urinário em Instituição de Longa Permanência para idosos \\ Factores asociados a la infección del tracto urinario en un Hogar para Ancianos
}

João Luis Almeida da Silva'
ORCID: 0000-0001-6191-7005

Cassiane Dezoti da Fonseca"

ORCID: 0000-0002-2118-8562

Eniva Miladi Fernandes Stumm"'I

ORCID: 0000-0001-6169-0453

Roseanne Montargil Rocha' ORCID: 0000-0001-5766-413X

Myria Ribeiro da Silva' ORCID: 0000-0003-2600-6577

Dulce Aparecida Barbosa" ORCID: 0000-0002-9912-4446

'Universidade Estadual de Santa Cruz. Ilhéus, Bahia, Brazil. "Universidade Federal de São Paulo. São Paulo, São Paulo, Brazil.

I" Universidade Regional do Noroeste do Estado do Rio Grande do Sul. Ijuí, Rio Grande do Sul, Brazil.

How to cite this article: Silva JLA, Fonseca CD, Stumm EMF, Rocha RM Silva MR, Barbosa DA. Factors associated with urinary tract infection in a Nursing Home. Rev Bras Enferm. 2021;74(Suppl 2):e20200813. https://doi.org/10.1590/0034-7167-2020-0813

Corresponding author: João Luis Almeida da Silva

E-mail: jlasilva@uesc.br

EDITOR IN CHIEF: Antonio José de Almeida Filho ASSOCIATE EDITOR: Alvaro Sousa

Submission: 07-17-2020 Approval: 10-15-2020

\begin{abstract}
Objective: to analyze the factors associated with urinary tract infection occurrence in institutionalized elderly. Methods: this is a cross-sectional, analytical, quantitative study with 116 elderly people from a Nursing Home. Urinary tract infection diagnosis was carried out through urine culture and clinical assessment. Demographic data and associated factors were obtained from medical records. Statistical analysis included bivariate analysis and logistic regression models. Results: the factors associated with urinary tract infection $(p<0.05)$ were being female; wheelchair user; diaper use; diuretic use; urinary and bowel incontinence; type 1 diabetes; benign prostatic hyperplasia; dehydration. Conclusion: this study revealed that it is important to consider non-modifiable factors such as sex and clinical comorbidities; however, dehydration, a modifiable factor, increased the chances of developing urinary tract infections by 40 times among institutionalized elderly and demands greater attention from the health team. Descriptors: Aged; Urinary Tract Infections; Nursing Homes; Risk Factors; Health Services for the Aged.
\end{abstract}

\section{RESUMO}

Objetivo: analisar os fatores associados à ocorrência de infecção do trato urinário em idosos institucionalizados. Métodos: estudo transversal, analítico, de abordagem quantitativa, com 116 idosos de uma Instituição de Longa Permanência. O diagnóstico de infecção urinária foi por meio de urocultura e avaliação clínica. Os dados demográficos e fatores associados foram obtidos dos prontuários. A análise estatística compreendeu análise bivariada e modelos de regressão logística. Resultados: os fatores associados à infecção de trato urinário $(p<0,05)$ foram: sexo feminino; cadeirante; uso de fraldas; uso de diuréticos; incontinência urinária e fecal; diabetes tipo 1; hiperplasia benigna de próstata; desidratação. Conclusão: o estudo revelou que é importante considerar os fatores não modificáveis como sexo e comorbidades clínicas, mas a presença de desidratação, um fator modificável, aumentou em 40 vezes a chance de desenvolver infecções de trato urinário entre os idosos institucionalizados e demanda maior atenção da equipe de saúde.

Descritores: Idoso; Infecções Urinárias; Instituição de Longa Permanência para Idosos; Fatores de Risco; Saúde do Idoso Institucionalizado.

\section{RESUMEN}

Objetivo: analizar los factores asociados a la ocurrencia de infección del tracto urinario en ancianos institucionalizados. Métodos: estudio transversal, analítico con abordaje cuantitativo, con 116 ancianos de um Hogar para Ancianos. El diagnóstico de infección del tracto urinario se realizó mediante urocultivo y evaluación clínica. Los datos demográficos y los factores asociados se obtuvieron de las historias clínicas. El análisis estadístico incluyó análisis bivariado y modelos de regresión logística. Resultados: los factores asociados a la infección del tracto urinario $(p<0.05)$ fueron: mujeres; silla de ruedas; uso de pañales; uso de diuréticos; incontinencia urinaria y fecal; diabetes tipo 1 ; hiperplasia prostática benigna; deshidración. Conclusión: es importante considerar factores no modificables como el sexo y las comorbilidades clínicas, pero la presencia de deshidratación, un factor modificable, aumentó 40 veces la posibilidad de desarrollar infecciones del tracto urinario entre los ancianos institucionalizados y exige una mayor atención por parte del equipo de salud. Descriptores: Anciano; Infecciones Urinarias; Hogares para Ancianos; Factores de Riesgo; Salud del Anciano Institucionalizado. 


\section{INTRODUCTION}

The Brazilian aging process can be observed, in the last decades, through continuous significant population increases in the demographic pattern. In 2015 , elderly people accounted for $12.31 \%$ of the general population, and the projection for 2025 is $19.0 \%$. In 2015, life expectancy increased from 75.44 years and the projection for 2025 is 78.74 years $^{(1)}$.

Chronic non-communicable diseases are prevalent in this population segment. Moreover, infections are a clinical complication that favors the increase in hospital admissions with high rates of morbidity and mortality. In this context, urinary tract infections (UTI), common in elderly people, stand out as a result of an interaction between bacterial virulence and the host's biological and behavioral factors. UTIs cause $15.5 \%$ of hospitalizations and $6.2 \%$ of deaths among the elderly population over 65 years old ${ }^{(2)}$.

Elder institutionalization has been an alternative to the lack of support conditions within the family. It is estimated that $40 \%$ of people aged 65 and over will need care in a Nursing Home $(\mathrm{NH})^{(3)}$.

Institutionalized elderly is considered a population at risk for UTI development, since several factors coexist, such as advanced age, comorbidities, immobilization and urinary tract interventions. In addition to the structure of co-habitation in $\mathrm{NH}$ s and the characteristic aspects of senescence and senility (phase in which anatomic-functional changes, biochemical and psychological changes occur), there is a decrease in the immune response, concomitant diseases and cognitive deficit that contribute to worse prognosis ${ }^{(4)}$.

From 12 to $30 \%$ of the occurrences present UTI at least once a year, which corresponds to twice as many as a person residing at home, in addition to being more susceptible to the more severe and more complicated forms of the disease ${ }^{(2)}$. Thus, 25 to $50 \%$ of UTIs occur in women and 15 to $40 \%$ in men, resulting in higher rates than those who live in communities or are hospitalized.

The context surrounding UTI prevention in institutionalized elderly should consider factors of the aging process itself and the NH's structure, which becomes a challenge for the care practice of the multidisciplinary team. Thus, investigations that characterize associated risk factors can promote the development of qualified and efficient infection control strategies in these care spaces for elderly people.

\section{OBJECTIVE}

To analyze the factors associated with urinary tract infection occurrence in institutionalized elderly.

\section{METHOD}

\section{Ethical aspects}

This research was approved by the Research Ethics Committees of Universidade Estadual de Santa Cruz and Universidade Federal de São Paulo.

\section{Design, period, place of study}

This is a cross-sectional study guided by STROBE carried out from July to December 2018 at an NH located in a municipality in southern Bahia.

\section{Population; inclusion and exclusion criteria}

This study was carried out with 116 elderly people. Elderly people aged 60 or over, of both sexes, institutionalized for at least 1 week were included. Elderly people using antibiotic therapy for UTI, using a bladder catheter or its removal less than 72 hours, hospitalization for less than 2 weeks were excluded.

\section{Study protocol}

McGeer's international criteria were used to diagnose UTI: urinalysis with pyuria ( $>10$ leukocytes per field), urine culture with bacteriuria greater than $105 \mathrm{CFU} / \mathrm{ml}$ associated with the presence of at least 2 of the components: fever $>38^{\circ}$, acute dysuria, suprapubic pain/tenderness, costovertebral angle pain/ tenderness, worsening or urgency of urination, current urinary incontinence ${ }^{(5-6)}$. Thus, urine samples were collected for laboratory analysis of all elderly people, following the Brazilian Society of Clinical Pathology/Laboratory Medicine's techniques and recommendations ${ }^{(7)}$. Collection with all elderly people subsidized the differentiation between symptomatic and asymptomatic.

In dehydration assessment, urinalysis with urine in amber color and density $>1.035$ was considered associated with physical examination (skin condition, turgor, elasticity, mucosal moisture, feeling of thirst) ${ }^{(5-6)}$.

To identify the associated factors, a structured form was used to collect information from medical records, composed of variables: age group - interval every 5 years - sex, education, bedridden, wheelchair user, continuous diaper use, personal hygiene, continuous diuretic use, polypharmacy - continuous use of more than 3 medications -, benign prostatic hyperplasia $(\mathrm{BPH})$, dehydration, urinary incontinence, bowel incontinence, type 1 diabetes, type 2 diabetes, acute kidney failure, chronic kidney disease, and cognitive impairment.

The Mini Mental State Examination (MMSE) was used to track cognitive impairment, considering the cutoff points based on elderly people's years of study according to the criteria of Brucki et al. $2003^{(8)}$. The difference of 2 points below the cutoff point was considered mild cognitive impairment; 4 points, below, moderate; more than 4 points below the cutoff point, severe cognitive impairment.

\section{Analysis of results, and statistics}

Descriptive statistics were used with calculation of mean and standard deviation (minimum and maximum) for the variables age, sex and education. Bivariate analysis was performed with all study variables. Logistic Regression Models were established in order to determine which statistically significant variables would be associated with the chances of developing UTI.

The first model was adjusted for the qualitative variables age group, sex, education and cognitive impairment in which the chance of an individual in a certain category was compared with an individual in a reference category. The variable age increase, derived from age group, was analyzed by assigning 5 years $(x+$ 5) from the first age group (60 to 65 years) and analyzing whether increasing age, from one age group to another, would interfere 
in cases of UTI. The reference category "male" was used to analyze differentiation between sexs. For education, the category "0" (illiterate) was used. Cognitive impairment was assessed by comparing the levels of mild, moderate and severe impairment from the MMSE cutoff points with those who did not have this clinical condition.

Subsequently, the final model of multivariate analysis was constituted, composed of statistically significant variables ( $p$ value $<0.05$ ) of previous phases. Statistical analyzes were performed with Fisher's exact test, with Odds Ratio calculations applying the software $\mathrm{R}$.

\section{RESULTS}

In the general sample of the elderly people studied (116), the age groups of 81 to 85 years old and above 85 years old figured prominently $(21.55 \%$ in each category), mostly long-lived, i.e., age over 80 years old, represented 43.1 $\%$ in the set. The mean age was 77.97 years (Standard Deviation (SD) +- 8.69), with a minimum age of 60 years and a maximum age of 102 years for both sexes. The female sex presented more than half of the number of institutionalized elderly in the sample (64.66\%). Education ranged from 0 to 9 years of study, with an average of only 2.12 years of study (SD + - 2.81). It was shown that almost $80 \%$ were in a situation of low education, $51.72 \%$ were illiterate ( 0 years of study) and $26.72 \%$ had 1 to 3 years of study.

Of the 116 urine samples, 51 had pyuria and bacteriuria (43.97\%) and of these, 39 were symptomatic elderly, with a prevalence of UTI of $33.62 \%$. Only 12 elderly people

(10.34\%) did not present other diagnostic criteria (asymptomatic).

Table 1 shows the first bivariate analysis with all variables in order to analyze the association of factors with UTI development compared to groups with UTI (39 elderly) and without UTI (77 elderly). The "bedridden" situational variable obtained only 1 record. Clinical variables "acute kidney failure" and "chronic kidney disease" did not present records among the elderly people in the study; therefore, they were removed from statistical analysis because they did not present enough information to assess their influence on ITU.

Age group (years)

60 to 65

76 to 80

$>80$

Sex

Female

Education (years of study)

4 to 7

$>7$ years

Situational characteristics

Wheelchair user

No

Continuous diaper use

No

Personal hygiene

No

Continuous diuretic use

No

Yes

Polipharmacy

Yes

Clinical characteristics No

Dehydration

No

Urinary incontinence

No

Bowel incontinence

No

Yes

Type 1 diabetes

No

Type 2 diabetes

Yes

Cognitive impairment

No

$$
\text { Yes }
$$
Note: ${ }^{*}$ Fisher's exact test;
only for elderly males.
Table 1 - Factors associated with urinary tract infection development among institutionalized elderly, 2018

\begin{tabular}{|c|c|c|c|c|c|}
\hline \multirow[b]{2}{*}{ Variables } & \multicolumn{2}{|c|}{ Urinary Tract Infection } & \multirow{2}{*}{$\underset{\text { value* }}{p}$} & \multirow{2}{*}{$\begin{array}{l}\text { Odds } \\
\text { Ratio** }\end{array}$} & \multirow{2}{*}{$\begin{array}{c}\text { Confidence } \\
\text { Interval - C } \\
(95 \%)\end{array}$} \\
\hline & $\begin{array}{r}\text { No }(n=77) \\
n \quad(\%)\end{array}$ & $\begin{array}{c}\text { Yes }(n=39) \\
n \quad(\%)\end{array}$ & & & \\
\hline
\end{tabular}

Sociodemographic characteristics

Benign Prostate Hyperplasia (BPH)***
$8 \quad(62) \quad 5 \quad(38)$

$\begin{array}{llll}9 & (69) & 4 & (31)\end{array}$

$\begin{array}{llll}10 & (62) & 6 & (38)\end{array}$

$\begin{array}{llll}34 & (68) \quad 16 & (32)\end{array}$

$\begin{array}{lllll}29 & (71) & 12 & (29) & 0.540\end{array}$

$\begin{array}{lllll}48 & \text { (64) } & 27 & \text { (36) } & 0.330\end{array}$

$40 \quad(67) \quad 20 \quad(33)$

$\begin{array}{llll}20 & (67) & 11 & (33)\end{array}$

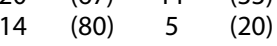

$3 \quad(50) \quad 3 \quad(50)$

$\left.\begin{array}{llllllll}30 & (57) & 23 & (43) & 0.040 & 1.54 & {[0.20} & -0.97\end{array}\right]$

$\begin{array}{llll}47 & (75) & 16 & (25)\end{array}$

$\left.\begin{array}{llllllll}47 & (75) & 16 & (25) & 0.041 & 2.25 & {[1.03} & -4.94\end{array}\right]$

$30 \quad(57) \quad 23 \quad(43)$

$\begin{array}{lllll}57 & (66) & 29 & (34) & 1.000\end{array}$

$20 \quad(67) \quad 10 \quad(33)$

$\left.\begin{array}{llllllll}63 & (72) & 24 & (28) & 0.023 & 2.81 & {[1.18} & -6.69\end{array}\right]$

$\begin{array}{llll}14 & (48) & 15 & (52)\end{array}$

$\begin{array}{lllll}9 & (64) & 5 & (36) & 1.000\end{array}$

$\begin{array}{llll}68 & (67) \quad 34 & (33)\end{array}$

$\begin{array}{llllllll}28 & (78) & 8 & (22) & 0.02 & 13.0 & {\left[\begin{array}{ll}1.8 & -293.0\end{array}\right]}\end{array}$

$\begin{array}{llll}1 & (20) & 4 & (80)\end{array}$

$\left.\begin{array}{cccccccc}71 & (89) & 9 & (11) & <0.001 & 40.1 & {[12.9} & -120.61\end{array}\right]$

$\left.\begin{array}{llllllll}49 & (75) & 16 & (25) & 0.031 & 2.7 & {[1.14} & -5.54\end{array}\right]$

$\begin{array}{llllll}28 & (55) & 23 & (45) & & \end{array}$

$\left.\begin{array}{llllllll}71 & (72) & 27 & (28) & 0.002 & 5.3 & {[1.79} & -15.42\end{array}\right]$

$\begin{array}{lllllll}6 & (33) & 12 & (67) & & & \end{array}$

$\left.\begin{array}{llllllll}75 & (69) & 33 & (31) & 0.019 & 7.02 & {[1.31} & -35.57\end{array}\right]$

$2 \quad(25) \quad 6 \quad(75)$

$\begin{array}{lllll}65 & (65) & 35 & (35) & 0.573\end{array}$

$\begin{array}{llll}12 & \text { (75) } & 4 & (25)\end{array}$

$\begin{array}{lllll}14 & (67) & 7 & (33) & 1.000\end{array}$

$\begin{array}{llll}63 & (66) & 32 & (34)\end{array}$ $\begin{array}{llll}16 & (67) & 8 & (33)\end{array}$

Note: *Fisher's exact test; ${ }^{* *}$ Odds Ratio $=$ Odds ratio with values only for variables with statistical significance $p$ value $<0.05 ; *{ }^{* *}$ Calculated

Concerning sociodemographic characteristics, age, sex and education did not show statistical significance. It is noteworthy that, in this analysis, the sex variable was assessed among elderly people of the same sex with and without UTI. The comparison between sexes is in the following model.

Concerning situational characteristics, being a wheelchair user showed an association ( $p=0.040, \mathrm{Cl}: 0.2-0.97$ ), inferring that being in this situation presents approximately 1 and a half chance for UTI occurrence. Continuous diaper use was 2 times 
more likely ( $p=0.041, \mathrm{Cl}: 1.03-4.94)$, and continuous diuretic use increased the chances of developing UTI by almost 3 times ( $p=0.023, \mathrm{Cl}: 1.18$ - 6.69).

Among clinical characteristics, BPH among elderly men was an important factor that can influence UTI, representing that an elderly person with $\mathrm{BPH}$ was 13 times more likely to present the condition ( $p=0.02, \mathrm{Cl}$ : 1.8 - 293.0). Urinary and bowel incontinences also contributed in this aspect, as they presented Odds Ratios of 2.7 ( $p=0.031, \mathrm{Cl}: 1.14-5.54)$ and $5.3(p=1.79, \mathrm{Cl}: 15.42)$, respectively. Like type 1 diabetes, in which elderly people with this pathology had a 7 times greater chance of falling ill due to UTI than a non-diabetic ( $p=0.019, \mathrm{Cl}: 1.31$ - 35.57).

However, among the most relevant clinical factors, dehydration stood out, as it increased the chance of developing UTI in institutionalized elderly people by up to 40 times $(p<0.001, \mathrm{Cl}$ : 12.9 -120.61). The other variables were not statistically significant for the association on screen.

The first logistic regression model, adjusted for variables age group, sex, education, and cognitive impairment, pointed out that being female doubled the chance of an elderly person presenting UTI ( $p=0.016, \mathrm{Cl} ; 1.02-5.06)$. The other variables did not show statistical significance.

Table 2 presents the final logistic regression model, with all variables that showed statistical significance in the study, in order to model the chances of developing UTI from the independent interference of these variables.

Table 2 - Factors Associated with Urinary Tract Infection Development Among Institutionalized Seniors, 2018

\begin{tabular}{lccc}
\hline Variables & $\begin{array}{c}\boldsymbol{p} \\
\text { value* }\end{array}$ & $\begin{array}{c}\text { Odds } \\
\text { Ratio** }\end{array}$ & $\begin{array}{c}\text { Confidence } \\
\text { Interval - CI } \\
\mathbf{( 9 5 \% )}\end{array}$ \\
\hline Female sex & 0.015 & 2.00 & {$[0.99-4.06]$} \\
Wheelchair user & 0.909 & - & - \\
Continuous diaper use & 0.039 & 2.20 & {$[1.5-4.80]$} \\
Continuous diuretic use & 0.03 & 2.90 & {$[1.20-6.55]$} \\
Dehydration & $<\mathbf{0 . 0 0 1}$ & 40.0 & {$[12.8-120.1]$} \\
Urinary incontinence & 0.030 & 2.80 & {$[1.10-5.6]$} \\
Bowel incontinence & 0.002 & 5.30 & {$[1.78-15.4]$} \\
Type 1diabetes & 0.021 & 7.00 & {$[1.30-34.0]$} \\
\hline
\end{tabular}

Note: *Fisher's exact test; **Odds Ratio $=$ Odds ratio with values only for variables with statistical significance $p$ value $<0.05$.

The wheelchair user variable was the only one that did not remain a predisposing factor for UTI development among the elderly people studied $(p=0.909)$. The other variables maintained patterns similar to the first models, i.e., being female $(p=0.015$, $\mathrm{Cl} 0.99-4.06)$ or using diapers continuously $(\mathrm{p}=0.039, \mathrm{Cl}: 1.5$ 4.8) doubles the chance of having ITU.

Diuretic use ( $p=0.03, \mathrm{Cl}: 1.20-6.55)$ and urinary incontinence $(p=0.03, C l: 1.1-5.6)$ are factors that almost triple this possibility.

Bowel incontinence or type 1 diabetes, if present, increases by $5(p=0.002, C l: 1.78-15.4)$ and 7 times $(p=0.021, C l: 1.3-34.0)$, respectively, the chances of UTI occurring.

However, the factor that continued to stand out for greater influence on UTI, among the institutionalized elderly studied, was dehydration, which potentiates the chances of developing the condition 40 times ( $p<0.001, \mathrm{Cl}$ : $12.8-120.1$ ).

\section{DISCUSSION}

Although the study presents a conjuncture of long-lived elderly in its majority, the age group factor in the models presented and in the 5-year increment, from the reference interval of 60 to 65 years, did not show any statistically significant influence. However, it is important to consider this audience when monitoring UTI cases due to their physiological conditions and weaknesses that aging itself imposes. In other association studies, older elderly people have higher UTI rates than younger ones due to dysfunctional characteristics that, over the years, intensify ${ }^{(4,9)}$.

In relation to the female sex, the feminization of old age is a social reflex and can be seen in long-term institutions as well, as confirmed by the study carried out, culminating in a more dedicated look at this public and its peculiar characteristics. The chance of developing UTI among elderly women, based on the analyzes performed, is twice as high as in men. Physiologically, the differentiations of the female and male genitourinary system may explain the circumstances of greater vulnerability of elderly people to UTI. The urinary meatus is more proximal to the perineum area, facilitating upward contamination, in addition to the high degree of local humidity. Furthermore, a larger bladder makes it possible to store urine for a longer time, resulting in an increased chance of bladder bacterial growth and UTI development. Moreover, in elderly women, there is impairment of the pelvic floor muscles, favoring the appearance of urinary incontinence, a risk factor for UTI occurrence ${ }^{(9)}$.

The third analysis model did not include the HPB factor to avoid confusion; however, it was possible to observe that among men with and without UTI, this factor was significant, allowing the chances of developing infection up to 13 times. In the search for literature on the specific association of BPH with UTI, there are no compelling and defining studies on the interaction between the two aspects; however, it is possible to infer that a conjuncture of anatomo-functional changes that elderly people with BPH experience may be related to UTI development. In other words, since the urethral lumen narrows as the prostate volume increases, this implies misshapen bladder storage, detrusor muscle hypertrophy, spasm and exhaustion, resulting in some symptoms such as nocturia, urinary urgency and incontinence ${ }^{(10)}$.

The situation of elderly people using wheelchair (wheelchair) is little explored in association with UTI development. The study did not show, in the latest analysis model, statistical significance, but even so it is important to highlight that elderly wheelchair users, in turn, are in a condition of immobility of the lower torso. Bladder voiding is often delayed by the difficulties in moving this elderly person to the toilet or changing diapers when he uses it. Long periods of urinary stasis, in several studies, have been shown to increase the risk of UTI(11). It is also noteworthy that the periodicity of diaper change is minimal in the institution studied, situations that can lead to bladder accumulation of urine or residues in diapers that can cause UTI.

In the researched institution, in addition to wheelchair users, there was 1 elderly person bedridden. In this regard, it is worth mentioning that in an American study on mobility and other predictors of hospitalization for UTI it is pointed out that immobility is a predisposing factor for UTI. They also found in that 
study that walking reduces the chance of hospitalization for UTI by almost $70 \%$ and increasing mobility in the bed or performing transfer reduces the same risk by $53 \%{ }^{(11)}$.

Urinary and bowel incontinence and diaper use, even though independent for UTI development in this study, raise the perspective that maintaining the perineal region with urine or feces stored for a long period in diapers, may explain the association of these factors with UTI. A Dutch study on factors related to UTI development identified urinary incontinence as an independent predictor with a 1.5-fold increase in risk ${ }^{(9)}$. Although the study designs are different, the independence of this factor to develop UTI (Odds Ratio of 2.80) was also clear. It is noteworthy that in Brazil and in most international studies, the association is demonstrated in numerous studies to the contrary, it analyzes UTI as a risk factor or predictor for incontinence, which limits the inferences, but reinforces the perspective for new research based on this line.

Concerning continuous diaper use, a Japanese study associated it with cystitis, but in a hospital context, it showed that there was recurrence or greater reinfection in those elderly who used diapers $^{(12)}$. In institutions for elderly people in Norway, a study found in its results a positive association between diaper use and $\mathrm{UTI}^{(13)}$. A survey of UTI with a cohort of elderly people with incontinence in $\mathrm{NH}$ in Belo Horizonte City, Brazil, showed an increase of 1.8 times the risk to develop UTI with diaper use ${ }^{(4)}$, a value close to what was found in this research (Odds Ratio of 2.20). However, even with satisfactory results, the authors are unanimous in stating that there is still a clinical dilemma and research challenges to effectively prove this association.

With regards to bowel incontinence, it was obtained, among the results, that the incontinent elderly had 5 times more chance of developing UTI. In other researches, the results reaffirm this relationship, in which patients with intestinal incontinence developed UTI three times more than patients without intestinal incontinence ${ }^{(9,13)}$. On the other hand, it is important to note that research with urine culture isolates, in addition to reaffirming this association, identified in their findings a high prevalence in $\mathrm{NH}$ of elderly people with Enterobacteriaceae producing extendedspectrum beta-lactamase, i.e., multi-resistant bacteria ${ }^{(14-15)}$. The authors also emphasize that those with intestinal incontinence should not sit or lie with feces for long periods, as it facilitates the transport of microorganisms, especially when in diarrheal situations. On the other hand, it is known that hand washing by direct care professionals is also essential to reduce bacteria carriage.

Considering this situation of incontinence and diaper use, it is considered that systematic change and hygiene would be conditions to reduce these factors, but it is not always possible in some $\mathrm{NH}$ s with a shortage of personnel. In the institution studied, the number of professionals performing direct care is low: 21 to 116 elderly people on alternate shifts, which interferes with the quality of care for elderly people.

It can be seen in studies of missed nursing care, when analyzing the impact that nursing care left unattended has on patients' outcomes, that the adequate level of nursing staff is an association factor for nosocomial infections ${ }^{(16-18)}$. As in hospital studies, researches in nursing homes in the USA have shown that several absent care were associated with a greater chance of developing UTI, especially those linked to comfort and hygiene procedures ${ }^{(18)}$. Unfortunately, in Brazil, there is no research directed at $\mathrm{NHs,} \mathrm{only} \mathrm{hospital} \mathrm{ones,}$ which makes some inferences and comparisons difficult.

It is common to observe that elderly people in $\mathrm{NH}$ present 3 to 4 situations of chronic illness, with diabetes being the most expressive, in the proportion of $10 \%$ to $30 \%{ }^{(19)}$. In the studied $\mathrm{NH}$, type 2 diabetes was the most prevalent, the same trend as other studies with elderly populations ${ }^{(19-20)}$, but it was not associated with UTI. However, a finding worth mentioning is type 1 diabetes, which presented itself as an associated factor, with an Odds Ratio of 7.00 in the final logistic regression model.

A possible explanation is related to autonomic neuropathy that causes damage to the genitourinary system and the effects that hyperglycemia has on immunity levels. The autonomic nervous system controls, among other organs, the bladder. Diabetes, when present, can affect the nerves in this region and trigger autonomic diabetic neuropathy. The risk of this condition increases the longer the diabetes has been present and is more prevalent in people who have had diabetes for at least 25 years, which is the case for many of elderly people. Among the consequences is urinary incontinence due to damage to the controlling innervations, incomplete bladder voiding, urinary retention, post-voiding residue and the consequent proliferation of bacteria that increase the risk of UTI (20).

The role of hyperglycemia is related to chemotaxis (locomotion of defense cells in tissues from the differentiation of chemical gradients) alteration, as it interferes with the adhesion of microorganisms to polymorphonuclear lymphocytes and leukocytes and reduces their phagocytic function ${ }^{(20)}$. The literature points out that altered blood glucose, observed through elevated glycated hemoglobin $(\mathrm{HbA} 1 \mathrm{c})$, is associated with the risk of acquiring UTI ${ }^{(20-}$ ${ }^{21)}$. Once again, it reinforces that, in elderly people with diabetes, there is a favorable environment for bacterial growth, in order to allow cases of UTI to stand out. Recently, another Indian research in this regard endorses that diabetes predisposes to complicated UTI, and the two associated factors increase the mortality rate in elderly people by almost $20 \%{ }^{(22)}$.

The greater relevance of this study stood out by showing that dehydration among elderly people in $\mathrm{NH}$ was the factor that was most associated with UTI, with an Odds Ratio of 40 times. Although analysis does not intend to relate factors of dehydration and diuretic use together in UTI development, it is important to consider its synergism. Diuretics interfere with increased urinary frequency and, consequently, in cases of urinary incontinence.

Factors such as adipsia, concerns about incontinence, access to fluids, presentation of fluids, the behavior of elderly people throughout their lives in hydration, impaired swallowing mechanisms, forgetting elderly people to drink fluids and the difficulty of professional teams in effectively monitoring water intake can be situations that promote a greater risk of dehydration among elderly people in $\mathrm{NH}$ and, consequently, in situations of $\mathrm{UTI}^{(23)}$.

Experimental studies have shown that urinary flow reduces the number of bacteria in the bladder by $99 \%{ }^{(11)}$. Thus, fluid intake would reduce the risk of UTI, given that flow and voiding frequency would interfere in reducing the amount of bacteria. However, the exact amounts of this intake and the liquids' composition characteristics are still little explored in clinical research, and results are incompatible and inconclusive on this mechanism ${ }^{(23)}$. 
On the other hand, a study in 4 nursing homes in the USA showed a $58 \%$ reduction in the average number of complicated UTI admissions (those that required the use of more effective antibiotics), increasing water intake through the administration of 16 ounces of daily liquid (equivalent to about $470 \mathrm{ml}$ ) ${ }^{(24)}$. In this case, it is considered that colored and sugary drinks, such as juices, for instance, would be a plausible alternative for the offer due to the visual and taste stimulation, of course, with due regard for necessary exceptions in the case of those with glucose limitations.

In line with this proposition of alternative and complementary ways to encourage hydration, a systematic review with 4,328 titles aimed to assess the effectiveness of interventions and environmental factors in increasing fluid intake and reducing the risk of dehydration in elderly people living in NHs. In the study, they identified a varied set of interventions, but the effectiveness of many of the methods employed raised a high risk of bias. Thus, they concluded that in order to reduce dehydration in $\mathrm{NHs}$ it is important to involve multiple strategies involving management, care team, considering elderly people's environmental and behavioral factors, taking care to use robust research methodologies to assess the effectiveness of these strategies in association ${ }^{(23)}$.

The presented scenario allows us to infer that associated factors with a greater chance of developing UTI are modifiable, therefore, likely to be reduced in the context of $\mathrm{NH}$, but point to strategies that demand changes in care flows and routines for elderly people. It is important to highlight that monitoring these factors subsidizes local infection control and case management.

\section{Limitations of the Study}

This study has limitations for larger generalizations, considering that the sample was intentional with all institutionalized elderly. Diaper use was limited to use and non-use, without demarcating the period that an elderly person spent with diaper, and there may be some bias in that sense. Prospective follow-up to assess incidence was not possible due to the variability of elderly people entering and leaving the institution due to death conditions or other situations.

\section{Contributions to Nursing}

The results found, in addition to encouraging new studies in health surveillance in $\mathrm{NH}$, which are few at the national level, also contribute to the proposal of continuing education to qualify the nursing team and caregivers in these spaces, given that they are professionals who develop care directly for elderly people. On the other hand, the results allow us to rethink the reorganization of $\mathrm{NH}$ spaces and routines and professional staff adequacy so that the changes and conducts before reducing UTI cases are really effective among elderly people.

\section{CONCLUSION}

The factors that demonstrated an effective association with UTI among institutionalized elderly people confirmed, as in other studies, that females, urinary and bowel incontinences and type 1 diabetes predispose elderly people to greater vulnerability to develop UTI.

Diuretic use and continuous diaper user were independently and positively associated as factors that increase the chances of UTI among these elderly people. However, it is important to consider that diuretic use may predispose to urinary incontinence and dehydration. On the other hand, diaper use is an element composed of the situation of bowel and urinary incontinence, as well as periodic hygiene, so it is the observation that they are necessary factors in UTI surveillance and require a different look that includes all these elements.

The scientific literature is conflicting in bringing information on water intake and UTI, reinforcing that there are mechanisms yet to be defined or studied on the effectiveness against UTI. In this regard, the present study is one more that gives strong evidence that there is an association between dehydration and chances of developing UTI. Intervention actions need to be carried out in the face of adequate water intake among elderly people who, due to their senescence, already have physiological imbalances that favor the condition.

\section{REFERENCES}

1. Instituto Brasileiro de Geografia e Estatística (IBGE). Projeções Populacionais [Internet]. 2018[cited 2018 Sec 12]. Available from: https:// www.ibge.gov.br/estatisticas-novoportal/sociais/populacao/9109-projecao-da-populacao.html

2. Cortes-Penfield NW, Trautner BW, Jump R. Urinary tract infection and asymptomatic bacteriuria in older adults. Infect Dis Clin North Am. 2017;31(4):673-88. https://doi.org/10.1016/j.idc.2017.07.002

3. Lini EV, Portella MR, Doring M. Fatores associados à institucionalização de idosos: estudo caso-controle. Rev Bras Geriatr Gerontol. 2016;19(6):1004-14. https://doi.org/10.1590/1981-22562016019.160043

4. Melo LS, Ecolel FF, Oliveira DU, Pinto TS, Vitoriano MA, Alcoforado CLGC. Infecção do trato urinário: uma coorte de idosos com incontinência urinária. Rev Bras Enferm. 2017;70(4):838-44. https://doi.org/10.1590/0034-7167-2017-0141

5. Toward Optmized Practic (TOP). Diagnosis and management of urinary tract infection in long term care facilities clinical practice guideline [Internet] 2015[cited 2018 Dec 12]. Available from: http://www.topalbertadoctors.org/download/401/urinary_tract_infection_guideline. pdf?20190922124328

6. Agência Nacional de Vigilância Sanitária (Anvisa). Critérios Diagnósticos de Infecções Relacionadas à Assistência à Saúde. Brasília: ANVISA; 2017. 86 p.

7. Recomendações da Sociedade Brasileira de Patologia Clínica Medicina Laboratorial: Coleta e Preparo da Amostra Biológica. Manole: Minha Editora, 2014. 
8. Brucki SMD, Nitrini R, Caramelli P, Bertolucci PHF, Okamoto IH. Sugestões para o uso do miniexame do estado mental no Brasil. Arq Neuropsiquiatr. 2003;61(3B):777-81. https://doi.org/10.1590/S0004-282X2003000500014

9. Caljouw MA, den Elzen WP, Cools HJ, Gussekloo J. Predictive factors of urinary tract infections among the oldest old in the general population. a population-based prospective follow-up study. BMC Med. 2011;9:57. https://doi.org/10.1186/1741-7015-9-57

10. Fabbri RMA, Pires SL. Infecção urinária. In: Freitas PY. Tratado de geriatria e gerontologia. Rio de Janeiro: Guanabara Koogan, 2002. p.449-456.

11. Rogers MAM, Fries BE, Kaufman SR, Mody L, McMahon LF, Saint S. Mobility and other predictors of hospitalization for urinary tract infection: a retrospective cohort study. BMC Geriatr. 2008;8:31. https://doi.org/10.1186/1471-2318-8-31

12. Watsubo $E$. [Diaper cystitis as recurrent cause of urinary infections in geriatric community hospital]. Nihon Ronen Igakkai Zasshi. Jap J Geriatrol. 2012;49(1):114-8. https://doi.org/10.3143/geriatrics.49.114 Japanese.

13. Omli R, Skotnes LH, Romild U, Bakke A, Mykletun A, Kuhry E. Pad per day usage, urinary incontinence and urinary infections in nursing home residents. Age Ageing. 2010;39(5)549-54. https://doi.org/10.1093/ageing/afq082

14. Yokoyama K, Uehara Y, Sasaki T, Hiramatsu K. Risk factors of fecal colonization with extended-spectrum $\beta$-lactamase-producing Enterobacteriaceae in special nursing homes in Japan. J Gen Fam Med. 2018;19(3):90-6. https://doi.org/10.1002/jgf2.161

15. Zhao SY, Zhang J, Zhang YL, Wang YC, Xiao SZ, Gu FF, et al. Epidemiology and risk factors for faecal extended-spectrum $\beta$-lactamaseproducing Enterobacteriaceae (ESBL-E) carriage derived from residents of seven nursing homes in western Shanghai, China. Epidemiol Infect. 2016;144(4):695-702. https://doi.org/10.1017/S0950268815001879

16. Smith GB. In-hospital cardiac arrest: is it time for an in-hospital 'chain of prevention'? Resuscit. 2010;81(9):1209-11. https://doi.org/10.1016/j. resuscitation.2010.04.017

17. Shin S, Park JH, Bae SH. Nurse staffing and nurse outcomes: a systematic review and meta-analysis. Nurs Outllook. 2018;66(3):273-282. https://doi.org/10.1016/j.outlook.2017.12.002

18. Nelson ST, Flynn L. Relationship between missed care and urinary tract infections in nursing homes. Geriatr Nurs. 2015 MarApr;36(2):126-30. https://doi.org/10.1016/j.gerinurse.2014.12.009

19. Villas Bôas PJF, Ferreira ALA. Infecção em idosos internados em instituição de longa permanência. Rev Assoc Med Bras. 2007;53(2):126-9. https://doi.org/10.1590/S0104-42302007000200016

20. Aswani SM, Chandrashekar U, Shivashankara K, Pruthvi B. Clinical profile of urinary tract infections in diabetics and non-diabetics. Australas Med J. 2014;7(1):29-34. https://doi.org/10.4066/AMJ.2014.1906

21. Ferreira RC, Barros CE, Braga AL. Perfil de Infecção urinária associada à taxa de glicemia alterada. RBAC [Internet]. 2016;48(4):346-51 [cited 2019 Jun 10]. Available from: http://www.rbac.org.br/artigos/perfil-de-infeccao-urinaria-associada-taxa-de-glicemia-alterada/

22. Kakde P, Redkar NN, Yelale A. Urinary tract infection in elderly: clinical profile and outcome. J Assoc Physicians India [Internet]. 2018[cited 2018 Dec 12];66(6):14-7. Available from: https://pubmed.ncbi.nlm.nih.gov/31331128/

23. Bunn D, Jimoh F, Wilsher SH, Hooper L. Increasing fluid intake and reducing dehydration risk in older people living in long-term care: a systematic review. J Am Med Dir Assoc. 2015;16(2):101-13. https://doi.org/10.1016/j.jamda.2014.10.016

24. Lean $\mathrm{K}$, Nawaz RF, Jawad S, Vincent C. Reducing urinary tract infections in care homes by improving hydration. BMJ Open Qual. 2019;8(3):e000563. https://doi.org/10.1136/bmjoq-2018-000563 